\title{
Músicos no Rio de Janeiro oitocentista: três contos de Machado de Assis
}

\section{Musicians in 19th century Rio de Janeiro: three short stories by Machado de Assis}

\author{
Denise de Quintana Estacio ${ }^{1}$
}

\begin{abstract}
Resumo: Os contos discutidos neste texto, "Cantiga de esponsais" (1883), "O machete" (1878) e "Um homem célebre" (1888), possuem em comum a presença central de um conflito interno, marcado pelo descompasso entre o desejo e a capacidade de composição, em todos protagonistas, o que, de certo modo, reflete a impossibilidade de traduzir a experiência brasileira na forma erudita. Nos três contos, as personagens centrais, homens das camadas populares e de ascendência africana, ilustram a vida de músicos no Rio de Janeiro oitocentista em três momentos deferentes - 1813, meados do século e anos 1870 - e, dessa forma, apresentam as contradições inerentes ao contexto urbano escravista do período. A música, assim como o trabalho dos homens livres, não abria espaço para a mobilidade social, porém inseria o músico em uma posição diferenciada no ambiente urbano. Mestre Romão, Inácio Ramos e Pestana possuem formação erudita e vivem em espaços reservados às camadas populares da cidade ao mesmo tempo em que convivem com grupos da elite e pessoas de gosto musical mais refinado. Sua profissão, portanto, torna-se uma peculiar marca de distinção que destaca ainda mais a realidade contraditória do próprio país, liberal e escravista ao mesmo tempo.
\end{abstract}

Palavras-chave: Machado de Assis; contos; músicos; Rio de Janeiro.

Abstract: The short stories discussed in this text, "Cantiga de esponsais" (1883), "O machete" (1878), and "Um homem célebre" (1888), have in common the central presence of an internal conflict in their protagonists that is marked by the mismatch between desire and compositional capacity, which might reflect the impossibility of translating the Brazilian experience in the erudite form. In the stories, the central characters, men of the popular strata and of African descent, illustrate the life of musicians in Rio de Janeiro in the 19th century in three different moments - 1813, mid-century and $1870 \mathrm{~s}-$ and, thus, present the inherent contradictions to the slave urban context of the period. Musical practice, like the labor of non-slaves, did not ensure social mobility, but it did place the musician in a different position in the urban environment. Mestre Romão, Inácio Ramos and Pestana have erudite training and live in spaces reserved for the city's popular strata while also dealing with elite groups and people with more refined musical taste. Their activity, therefore, becomes a peculiar mark of distinction that further highlights the contradictory reality of the country itself, liberal and slave at the same time.

Keywords: Machado de Assis; short stories; musicians; Rio de Janeiro.

\section{Música e músicos no Rio de Janeiro oitocentista}

O presente texto busca efetuar uma leitura de três reconhecidos contos de Machado de Assis que lidam com a questão da música e da vida de músicos - “Cantiga

\footnotetext{
${ }^{1}$ Doutoranda em Letras na UFRGS.
} 


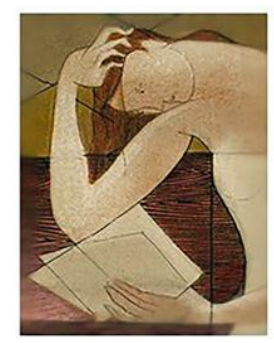

de esponsais", publicado em A Estação, em 1883; "O machete", publicado no Jornal das Famílias, em 1878; e "Um homem célebre", publicado na Gazeta de Notícias, em $1888^{2}$ - no Rio de Janeiro, em três momentos diferentes do século XIX. Cada história apresenta um eixo comum que, apesar das condições diversas do fazer artístico, atravessa a vida das personagens principais: a contradição inerente à condição de mestiço e letrado em uma cidade escravista. Segundo Wisnik (2004, p. 18), em "Um homem célebre", Machado faz

uma curiosa e penetrante análise da vida musical brasileira em fins do século XIX, armando uma equação nada simples, em cujas incógnitas desenham-se precocemente linhas do destino da música popular urbana no Brasil, para dizer pouco. Porque, entre outras coisas, [...] Machado acaba — se não revelando - resvalando em algo que nunca disse de si mesmo, em lugar nenhum: a condição do mulato.

Ao adicionarmos os outros dois contos aqui estudados, pensamos ser possível estender essa afirmação para o oitocentos brasileiro, já que "Cantiga de esponsais" retrata a condição de músico no período colonial, enquanto que "O machete" se passa em meados do século. A possibilidade de leitura desses contos a partir da representação realista de seu contexto histórico, como um panorama da construção do campo musical no Rio de Janeiro do século XIX, encontra-se em consonância com a afirmação de Avelar (2011, p. 186) de que

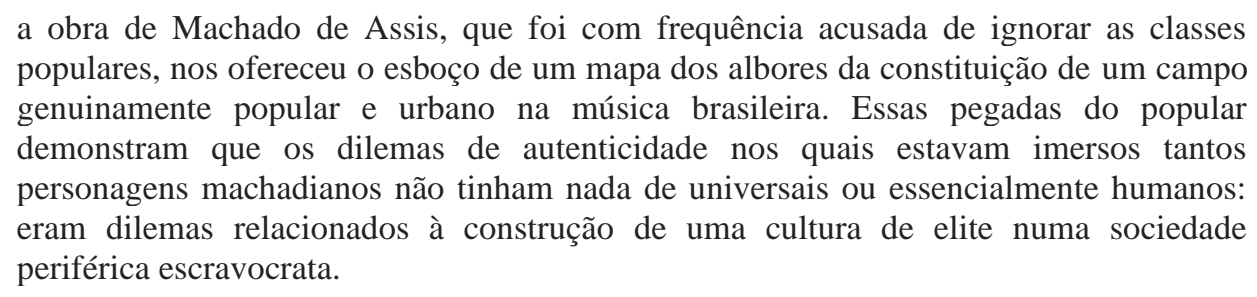

Com o destaque dado à formação de uma música popular e urbana, não se pode deixar de lado o papel que a experiência da vida no Rio de Janeiro ocupa na construção dos músicos machadianos. Nunes (2008, p. 76) afirma que

\footnotetext{
2 Dois destes contos viriam a ser publicados posteriormente em livros: "Cantiga de esponsais", em Histórias sem data, de 1884; e "Um homem célebre”, em Várias histórias, de 1895.
} 


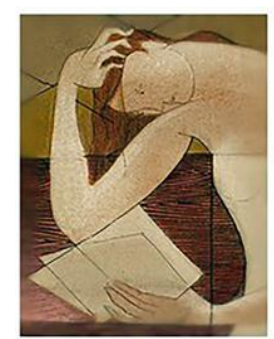

os artistas ocupavam uma posição social peculiar na estrutura social do Segundo Império, situando-se entre as classes médias e o grau mais baixo da hierarquia social, ocupado pelos escravos. Juntam-se a trabalhadores livres como operários, lavradores assalariados, trabalhadores braçais e manuais, como artesãos, tipógrafos, marceneiros.

O modo com que Machado se utiliza do espaço urbano em sua prosa estabelece uma conexão entre ficção e realidade. A presença da cidade na narrativa faz parte de um procedimento amplo e cuidadoso de representação da materialidade histórica por parte do escritor, mesmo que evitasse o uso de quadros descritivos. Desse modo, os espaços em que vivem e circulam, bem como os grupos e as práticas sociais de que fazem parte, permitem que se efetue uma leitura cruzada entre a condição de afrodescendente e o lugar social ocupado pelas personagens.

\section{2 "Cantiga de Esponsais" e o músico na cidade colonial}

Romão Pires (Mestre Romão), protagonista de "Cantiga de esponsais", contava com aproximadamente 60 anos em 1813, ano em que se passa a ação do conto. Vivendo durante o período colonial, mas após a chegada da família real portuguesa ao Rio, nascera na região portuária ("no Valongo ou por esses lados”, ASSIS, 2008, p. 363), aproximadamente em 1750. O detalhe do local de nascimento implica antepassados escravizados e aponta para a possibilidade de Mestre Romão ser negro ou mestiço. O músico é descrito como muito popular e respeitado - na abertura do conto, rege a orquestra na Igreja do Carmo -, talentoso na execução das missas que, no entanto, não são de sua autoria. "Circunspecto, triste, indiferente e calado" (ASSIS, 2008, p. 363-64), sua principal frustração é a incapacidade de compor.

A partir do fracasso na finalização de um canto esponsalício iniciado quando de seu casamento, o viúvo Mestre Romão é caracterizado como um homem que não consegue encontrar o compasso entre seus sentimentos e as possibilidades de composição que sua formação oferece: "Como um pássaro que acaba de ser preso, e forceja por transpor as paredes da gaiola, abaixo, acima, impaciente, aterrado, assim batia a inspiração de nosso músico, encerrada nele, sem poder sair, sem achar uma porta, nada" (ASSIS, 2008, p. 364). Essa imagem parece desenhar um paralelo entre a 

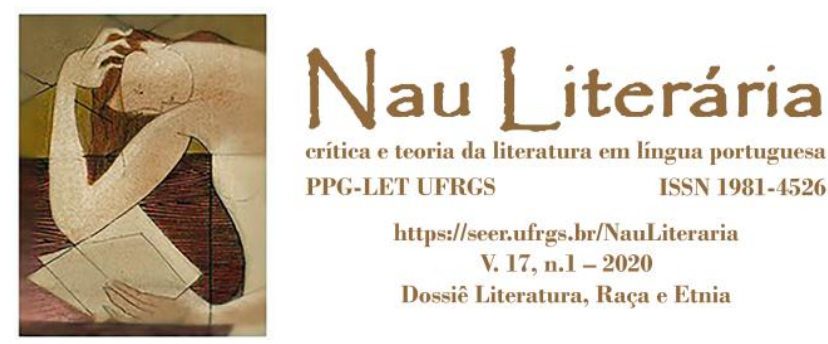

experiência da escravidão e a impossibilidade da criação artística nos moldes trazidos pelos europeus - "muitas óperas e missas, um mundo de harmonias novas e originais" (ASSIS, 2008, p. 364). Para Wisnik (2004, p. 15), “o horizonte dessa impossibilidade [de composição] encontra-se nos desvãos insondáveis da psique, numa latência sem objeto, em suma, numa prisão interior", o que nos leva a considerar a incompatibilidade entre a condição de homem livre e a presença da escravidão de africanos no Rio de Janeiro, as duas realidades em conflito na vida do protagonista.

Em sua casa "sombria e nua" (ASSIS, 2008, p. 364), o cravo existente servia apenas para estudo. A moradia localizava-se na Rua da Mãe dos Homens (Figura 1), como era conhecido o trecho da Rua da Alfândega (assim nomeada desde 1716) compreendido entre a Rua do Ouvidor e a da Quitanda, que levava o nome da igreja ali localizada. Era uma rua de caráter comercial desde a abertura dos portos, com muitos moradores e comerciantes estrangeiros (ingleses, libaneses e sírios, alemães), chegando a ser apelidada de "rua alemã" da cidade. Segundo Ferdinand Denis, devido a seu perfil de comércio, era muito frequentada por escravizados carregadores que levavam os produtos nas costas ou os puxavam em carros de carga chamados 'da Alfândega' (GERSON, 1965, p. 82. Ver Figuras 2 e 3).

O contraste entre as atividades que circundavam Romão - e, quem sabe, lembravam-no de suas origens - e o desejo de expressão de uma interioridade que se identificava com o sublime de certo modo define a frustração do músico. Não por acaso, é na vizinha recém-casada que a frase musical da cantiga que dá nome ao conto encontra o fechamento, pela sintonia entre a experiência da felicidade do casamento e a expressão artística desse sentimento. 


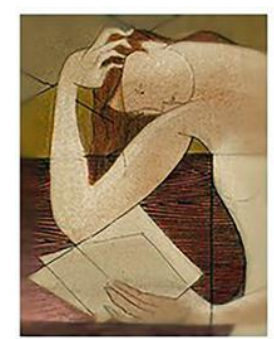

Nau Literária

erítica e teoria da literatura em língua portuguesa

PPG-LET UFRGS ISSN 1981-4526

https://seer.ufrgs.br/NauLiteraria

V. 17, n.1 - 2020

Dossiê Literatura, Raça e Etnia

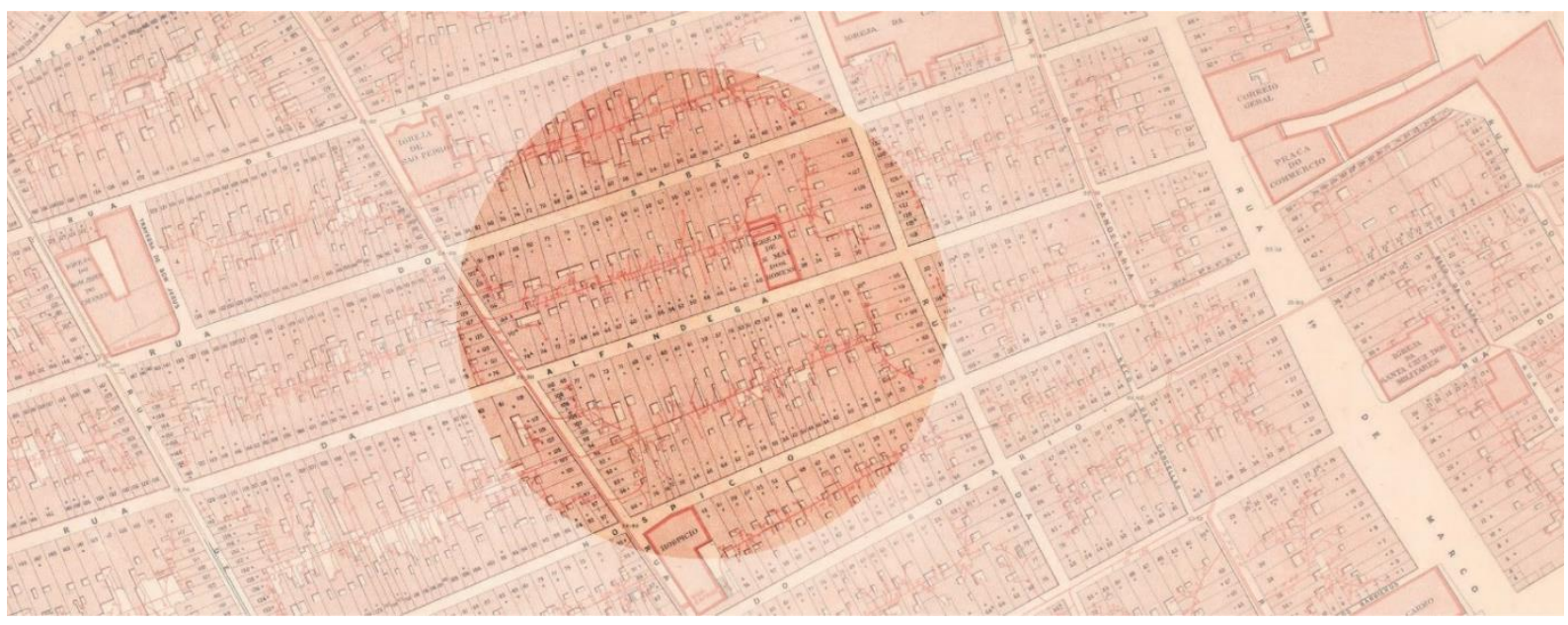

Figura 1. A rua da Mãe dos Homens. Detalhe de Gotto (1871).
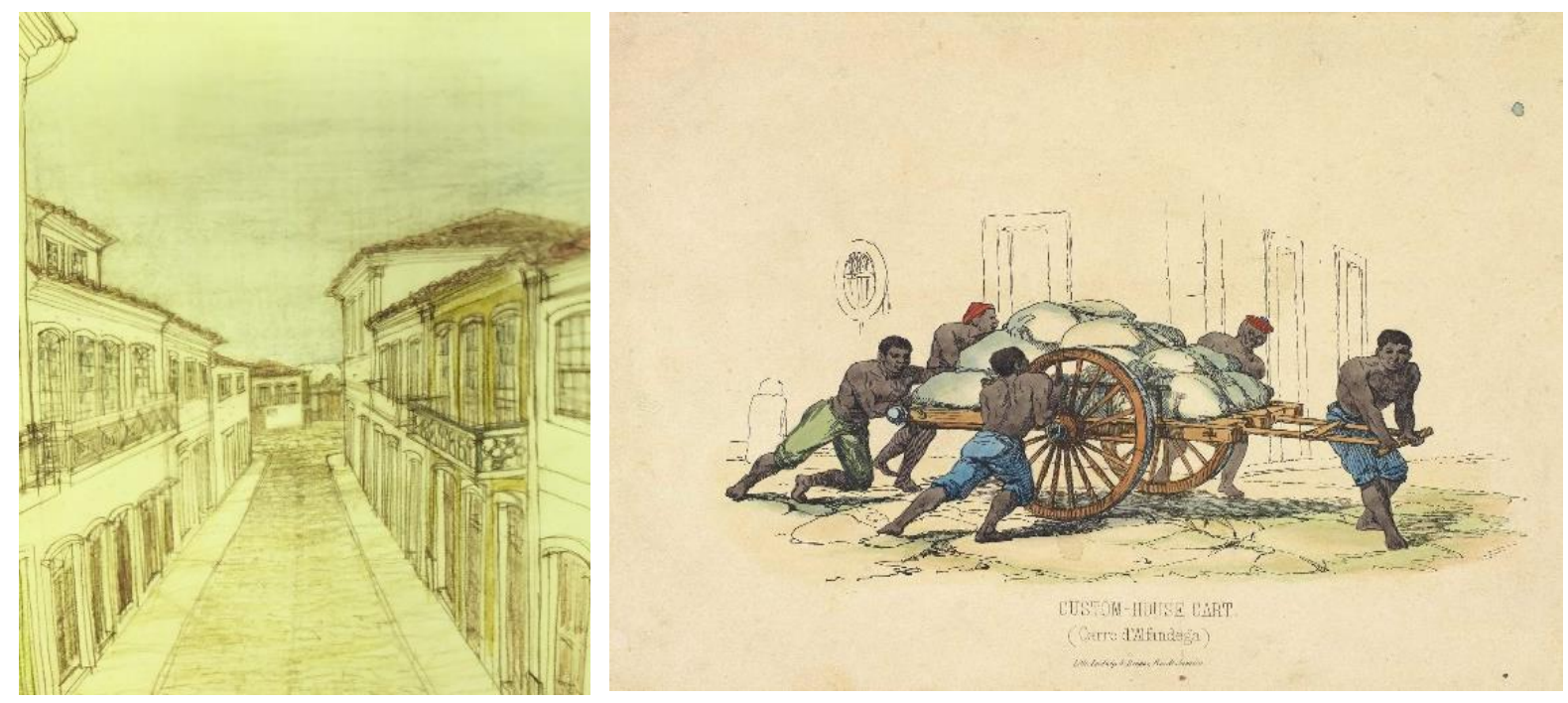

Figuras 2 e 3. Desenho conjectural da rua da Alfândega no período colonial (Fonte: Cavalcanti, 2016, p. 23) e Custom-house Cart, de F. G. Briggs (Fonte: Acervo Digital da Biblioteca Nacional).

A personagem "não se realiza em termos subjetivos ou objetivos, psicológica ou socialmente, não se identifica como artista; é músico em virtude de uma ocupação no cargo, um prestador de serviços, ainda que competente no que faz" (NUNES, 2008, p. 84). Ao mesmo tempo, ele não se situa propriamente entre os brancos, onde não é visto como mais que entretenimento, alguém que próprio narrador afirma que "sabia música como gente" (ASSIS, 2008, p. 365), ou entre os negros escravizados, como Pai José, 


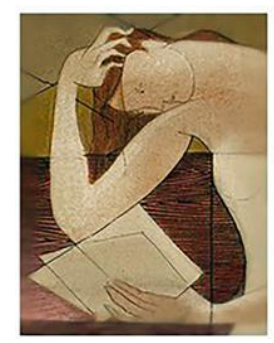

"sua verdadeira mãe" (ASSIS, 2008, p. 363), o mais próximo a um familiar que ele possui. Assim, Mestre Romão ocupa um entre-lugar na sociedade do período, cujo resultado é uma personagem cindida, espelhada pela dissociação entre experiência e composição.

\section{3 "O machete" e o músico em meados do século XIX}

Com "O machete", somos apresentados a "um dos registros machadianos mais notáveis da irrupção da cultura popular urbana" (AVELAR, 2011, p. 180) e "talvez o mais circunstanciado testemunho sobre a trabalhosa e sacrificada formação de um músico pobre devotado à música clássica em nosso meio" (WISNIK, 2004, p. 19). Inácio Ramos, sua principal personagem, possui origem pobre, sendo filho de um músico da Capela Imperial que lhe ensinou os rudimentos da música e das letras. Muito cedo revelou sua vocação, tornando-se competente rabequista, seu meio de vida. Com a visita de um violoncelista alemão à corte, toma contato com o instrumento que decide ser seu ideal artístico pela severidade que comunicava. Após a morte do pai, passa a viver só com a mãe, que ocupa o lugar de musa e de audiência melancólica e séria, em consonância com o espírito do musicista. Na vivaz, "mundana e jovial” (ASSIS, 2008, p. 1567) Carlotinha, com quem se casou após a morte da mãe, na tentativa de preencher a falta da senhora falecida, encontra uma audiência falsamente entusiasmada, cuja índole é oposta à sua.

$\mathrm{Na}$ ausência de indicadores temporais, podemos inferir, pelo fato de o pai de Inácio ser músico da imperial capela - instituição fundada com a chegada da família real portuguesa e que, até a ascensão de D. Pedro I, chamava-se real capela - e pela ênfase na escola romântica e sua preferência pela elite letrada brasileira, que o conto se passa em meados do século XIX, já no Segundo Reinado. Inácio vive no subúrbio, em local não identificado pela narrativa, fato não usual na prosa machadiana:

"Moravam ambos em lugar afastado, em um dos recantos da cidade, alheios à sociedade que os cercava e que os não entendia". As razões desse isolamento eram, conforme já observamos, principalmente devido à condição de outsiders que os músicos e trabalhadores braçais e manuais ocupavam na sociedade de classes em formação, já que 


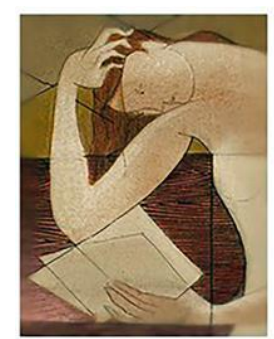

as ocupações braçais ou manuais eram principalmente realizadas por escravos e as classes superiores ainda não viam o trabalho do corpo ou das mãos como uma atividade nobre, ou mesmo digna. (NUNES, 2008, p. 77).

Assim, Inácio divide a música entre as instâncias do ofício - a rabeca - e da arte - o violoncelo -, separando-as e relegando esta última a "traduzir as impressões mais sublimes do espírito", a sua "arte doméstica" (ASSIS, 2008, p. 1568). O arranjo encontrado será submetido a um tensionamento pela chegada de dois estudantes de Direito, Amaral e Barbosa, este músico também, que, no entanto, tocava, no machete do título, "cantiga do tempo e da rua, obra de ocasião" (ASSIS, 2008, p. 1570). A popularidade que Barbosa encontra na vizinhança e, principalmente, em Carlotinha leva Inácio a questionar toda sua formação. Inicialmente, pensa em um modo de integrar os dois instrumentos em um "concerto para violoncelo e machete", porém, com o abandono da esposa, que acaba fugindo com Barbosa, tomado pela tristeza e pela loucura, aceita que "o machete é o melhor" (ASSIS, 2008, p. 1573), ou seja, que a música popular, na medida em que alcança o seu público, é superior à erudita. Acerca dessa questão, Wisnik (2004, p. 20) afirma

que Machado se depara [...] com a identificação de uma fratura, operante no meio cultural brasileiro, entre o repertório da música erudita, que está longe de fazer parte de um sistema integrado de autores, obras, público e intérpretes, e a emergência de um fenômeno novo, uma música popular urbana que desponta para a repercussão de massas, a identificação com a demanda do público e a normalização como mercadoria.

A dualidade aqui encontra-se razoavelmente resolvida até a chegada de Barbosa, que rompe o frágil equilíbrio que Inácio conferiu às duas instâncias, trabalho e arte. Os gêneros clássicos europeus ocupam um lugar superior, representando um ideal que, embora inatingível de modo geral, ainda pode ser apreciado por um seleto grupo de pessoas de gosto refinado, tornando-se uma peculiar marca de distinção: "o texto supõe e promove a identificação positiva com o mundo representado pelo violoncelo, em clara oposição ao mundo representado pelo cavaquinho" (WISNIK, 2004, p. 20), a rabeca ocupando uma posição intermediária neste trio de instrumentos de corda.

Assim, "Inácio Ramos compõe, mas não tem tato social e praticamente não se torna reconhecido ou popular em seu meio social (ao qual só pertence por herança e 

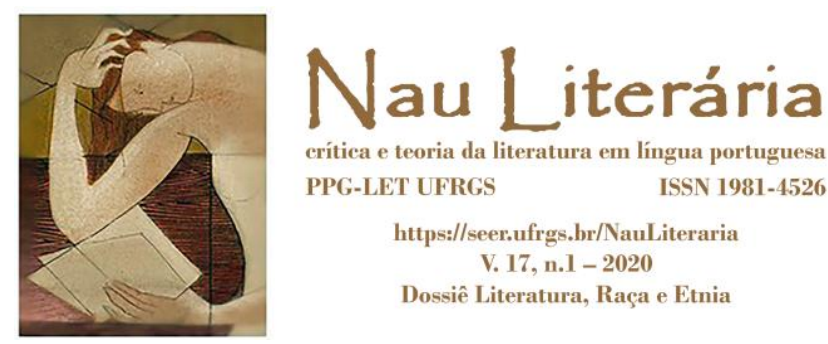

capital cultural familiar), pois os saraus e reuniões já assimilavam bem mais as formas musicais populares" (NUNES, 2008, p. 84). Na história narrada em "O machete", o entre-lugar ocupado pelo homem letrado de origem africana - a julgar pela breve caracterização da mãe de Inácio, "cuja alma parecia superior à condição em que nascera" (ASSIS, 2008, p. 1566) - e pobre o coloca em uma situação de estranhamento em relação às duas esferas entre as quais circula, sem conseguir pertencer a nenhuma.

Por isso, o conflito que se estabelece entre o músico e seus ouvintes mais próximos - esposa e vizinhos -, quando atinge a interioridade da personagem, leva-o à percepção da impossibilidade de conciliação entre a herança popular e a formação erudita. A fratura, revelada pelo surgimento de um triângulo onde antes havia um duo, entre público - representado por Carlotinha -, artista erudito e artista popular, demonstra uma mudança em relação à condição de mestre Romão: vive-se a transição para o surgimento de uma música de caráter popular e urbano, cujo próximo momento pode ser evidenciado no conto a ser analisado (AVELAR, 2011, p. 180). O machete do título representa "em definitivo o divórcio entre o sonatismo erudito e a experiência social real” (AVELAR, 2011, p. 185) e essa cisão, não elaborada, acaba por levar o protagonista à loucura.

\section{4 "Um homem célebre" e a transição dos anos 1870}

Pestana, o protagonista de "Um homem célebre", não encontra dificuldade para compor as polcas pelas quais é famoso não só em seu círculo, suas canções alcançando popularidade imediata em toda cidade. Em Pestana, como em Mestre Romão e em Inácio Ramos, revela-se uma oposição, porém de natureza diferente. Neste conto, o músico oscila entre a "inspiração real e pronta" (ASSIS, 2008, p. 466) que gera suas canções populares, e o desejo de compor peças clássicas e eruditas, como a dos compositores europeus cujos quadros adornam suas paredes "como santos de uma igreja" (ASSIS, 2008, p. 465). De certa forma, essa dualidade expressa a própria origem do músico, filho nunca reconhecido de um padre que o educara e que também deixara, como herança, os bens que Pestana possuía - uma "casa velha, escada velha, um preto 

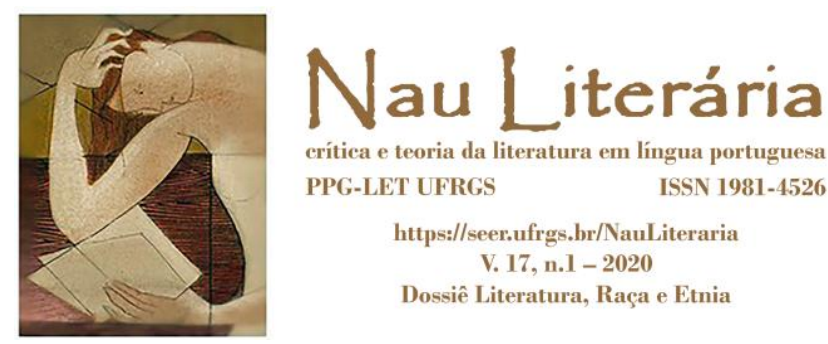

velho que o servia" (ASSIS, 2008, p. 465) - e o gosto pela música. Ele recebe a contragosto os cumprimentos por sua obra, e apenas sente-se feliz quando convidado a tocar músicas de gêneros requintados. Busca a fonte de inspiração clássica no casamento com uma viúva tuberculosa, cujo gosto musical semelhante não é tão atrativo como sua morte iminente. A perda da esposa o inspira a iniciar um réquiem para despedir-se não apenas dela, mas também da carreira de compositor. O esforço para silenciar "a musa de olhos marotos e gesto arredondado, fácil e graciosa"3 (ASSIS, 2008, p. 467), que surgira pela primeira vez em 1871, ano da promulgação da Lei do Ventre Livre, revelou-se inútil: não só o réquiem permaneceu inacabado como em poucos anos precisou voltar a compor polcas para viver.

Pestana vive na região do mangue, em 1875, tempo e espaço claramente demarcados neste conto. O percurso de Pestana do sarau da viúva Camargo até sua casa - rua do Areal, rua Formosa, rua do Aterrado (Figura 4) - situa todas as personagens nas camadas médias e populares da sociedade fluminense do século XIX. O artista vive na Cidade Nova, área inicialmente ocupada por africanos livres ou fugitivos e que abrigara, nas primeiras décadas do oitocentos, chácaras de famílias abastadas, passando, no terço final do século, a ser local de moradia de trabalhadores livres, imigrantes, pequenos comerciantes e burocratas. Na década de 1870, a Cidade Nova tornou-se o local com o maior número de cortiços da cidade (PINTO, 2007). Os ritmos populares da moda, como as polcas do protagonista, embalavam as festas da região, que viria a ser conhecida posteriormente como berço do samba.

\footnotetext{
${ }^{3}$ Wisnik (2004, p. 18) destaca a semelhança entre a descrição da musa da polca e a descrição de Carlotinha, esposa de Inácio Ramos, de "O machete", "mocinha de movimentos 'vivos e rápidos', de 'rosto amorenado, olhos negros e travessos"”.
} 


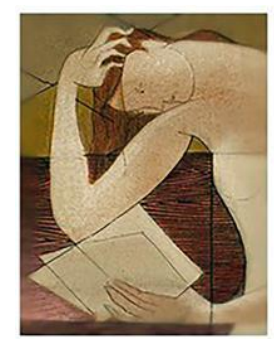

Nau Literária

PPG-LET UFRGS ISSN 1981-4526

https://seer.ufrgs.br/NauLiteraria

V. 17, n.1 - 2020

Dossiê Literatura, Raça e Etnia

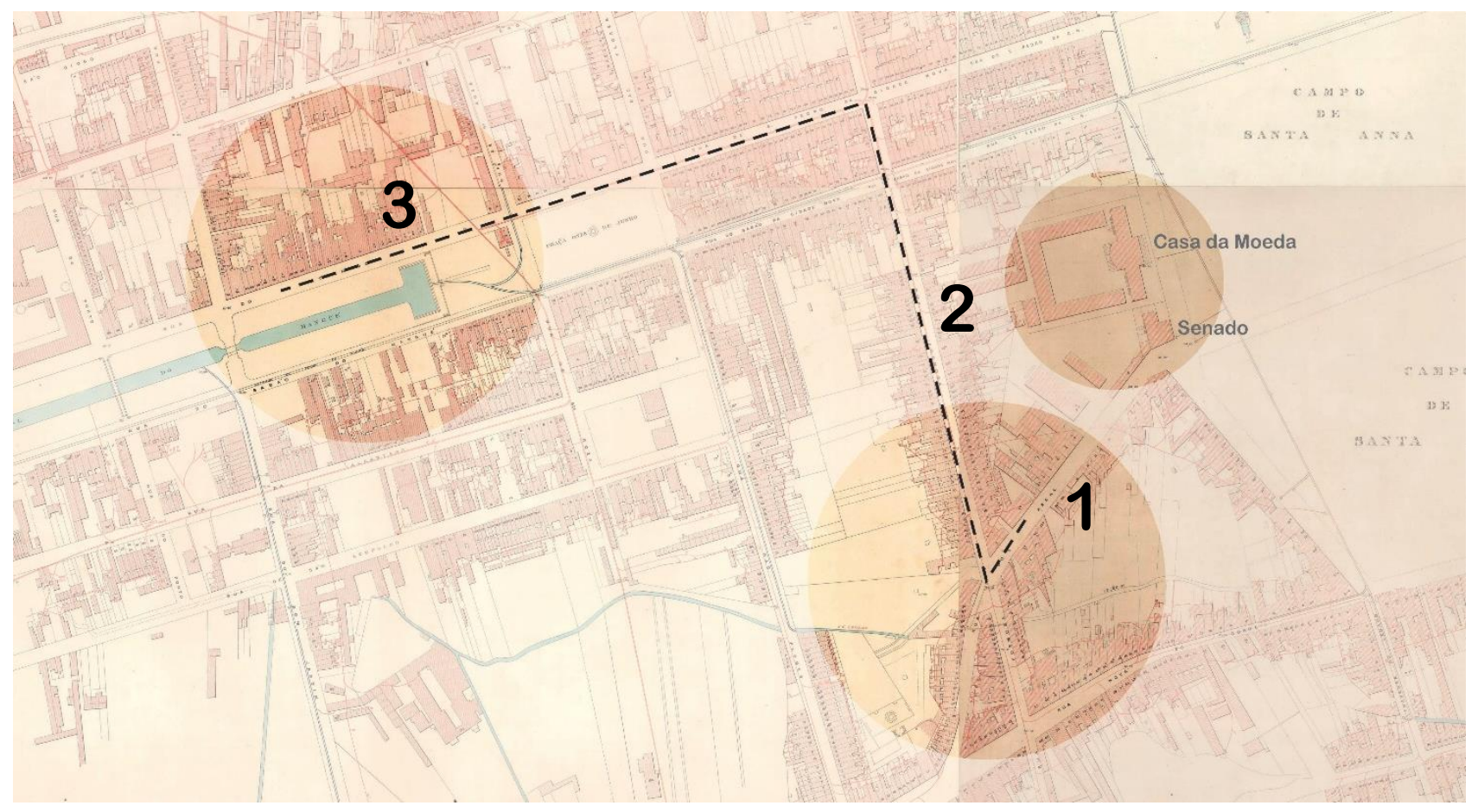

Figura 4. Santana e Cidade Nova: o percurso de Pestana - rua do Areal (1), rua Formosa (2), rua do Aterrado (3). Detalhe de Gotto (1871).

Wisnik (2004, p. 25-26) identifica nas populares polcas de Pestana mais uma elipse machadiana. As canções tão apreciadas fariam parte de um gênero em transição, o maxixe, que partindo do original europeu viria a desembocar no samba carioca:

no mesmo movimento com que deixa ver a obviedade gritante do sucesso e da moda importada, o escritor está registrando um objeto oculto, e quase ainda não nomeável, inscrito sutilmente no primeiro: é que a década de 1870 acusa já o processo de transformação da polca naquela outra coisa que se chamará maxixe, por obra dos deslocamentos rítmicos que acompanham a africanização abrasileirada dessa dança europeia.

Sobre essa transição, Avelar (2011, p. 175) afirma que

é escondendo-se sob formas hifenadas (polca-brasileira, polca-lundu ou polca-cateretê) que se constituirá o primeiro grande fenômeno musical popular e urbano do Brasil, o maxixe. A polca tem um lugar privilegiado como prática cultural híbrida, em trânsito, definidora da nacionalidade. 


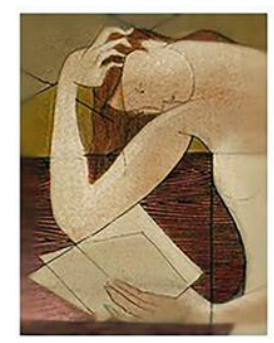

Assim, o protagonista de "cabelo negro, longo e cacheado, olhos cuidosos" (ASSIS, 2008, p. 464) - em nenhum momento abertamente descrito como mestiço ${ }^{4}$ enfrenta uma dualidade interna similar à de mestre Romão, com a diferença de que Pestana encontra uma forma para se expressar - importada da Europa, porém transformada pela cultura popular de matriz africana; apenas a rejeita por não se adequar a um ideal clássico elevado. Ainda para Wisnik (2004, p. 26), a omissão do nome maxixe resulta do "processo de recalque em ambientes brancos, elitizados, domésticos, senhoriais" - como o retratado na casa da patusca viúva. "Ligado aos ambientes populares da Cidade Nova, inseparáveis dos contingentes de escravos e das músicas tocadas e dançadas por negros, e propagado inicialmente nos ambientes boêmios contíguos à vida noturna, ao teatro de revista e à prostituição", encontramos aqui o nexo entre o ambiente em que Pestana morava e a música que produzia. Do mesmo modo que mestre Romão, o seu ideal é incompatível com a realidade em que vive, porém Pestana encontra, na africanização da canção europeia, o ponto de encontro entre a expressão artística e a experiência urbana brasileira.

O conflito de Pestana, porém, encontra-se em outra esfera, ainda que também relacionada à incompatibilidade existente entre a realidade brasileira e o ideal europeu: o músico "não se contenta em ser um homo laborans e empregar apenas suas habilidades naturais, como o faz para compor polcas, por exemplo; quer se tornar um homo faber, com consciência e identificação com o produto de seu trabalho, quer compor peças eruditas, mas não consegue" (NUNES, 2008, p. 85). Assim, Pestana transita em um momento de divisão entre música erudita e popular, com a primeira representando "a essência, a coisa em si”, conforme identifica Gledson (2006, p. 64).

De certo modo, a condição do artista espelha a situação do Brasil do período, liberal e conservador ao mesmo tempo, mas que igualmente almeja um modelo social

\footnotetext{
${ }^{4}$ Wisnik (2004, p. 39) associa o título da primeira polca mencionada no conto "Não bula comigo, nhonhô" à violência sexual que as escravizadas e crias da casa sofriam nas mãos de seus senhores. A origem não esclarecida do protagonista do conto aponta para essa realidade, mencionada abertamente em outros trabalhos de Machado, como os contos "Virgínius", de 1864, e "Mariana", de 1871, e o poema "Sabina”, publicado em Americanas, em 1875.
} 

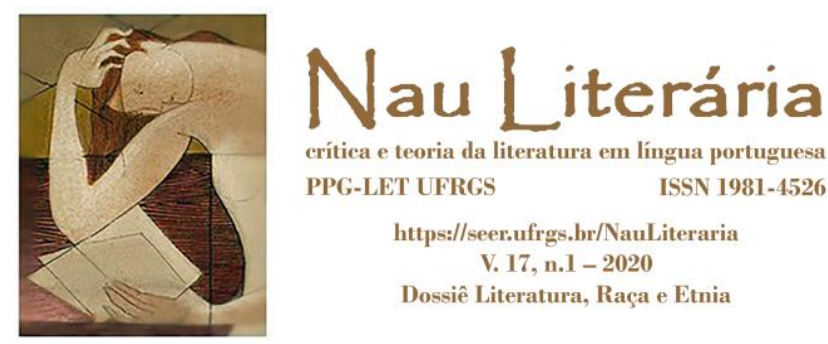

inatingível e, mesmo, inadequado: o desejo de uma civilização branca europeia em um país escravista e miscigenado. As canções compostas por Pestana eram nomeadas pelo editor, que buscava popularidade e, por isso, concebia os títulos em "alusão a algum sucesso do dia - ou pela graça das palavras" (ASSIS, 2008, p. 467). A dualidade do Império Brasileiro parece ser perfeitamente registrada pelo modismo passageiro das canções escritas para serem substituídas e logo esquecidas, cujos nomes são dados pelas circunstâncias, como Pestana revela na "única pilhéria que disse em toda a vida" (ASSIS, 2008, p. 470), aludindo à semelhança entre a presença de conservadores ou de liberais no poder.

\section{Dualidade brasileira: os músicos e a música em contexto escravista}

Como vimos, o conflito entre a impossibilidade de traduzir a experiência brasileira na forma erudita não é o único ponto que une os protagonistas músicos destes contos: todos eles fazem parte das camadas populares e, provavelmente, possuem origem africana.

A música, assim como o trabalho dos homens livres, não abria espaço para a mobilidade social - como ilustra o caso do pai de Carlotinha, "homem que trabalhou a vida toda como um mouro para morrer pobre" (ASSIS, 2008, p. 1567). O narrador de "O machete" informa que o pai de Inácio fora muito pobre e que "as posses de Inácio Ramos eram poucas; ainda assim ele sabia dirigir a vida de modo que nem o necessário lhe faltava nem deixava de satisfazer algum dos desejos mais modestos" (ASSIS, 2008, p. 1568) da esposa. Pestana vivia na Cidade Nova e, no momento em que decide parar de compor suas polcas, perde tudo o que herdara do padre/pai. Mestre Romão habitava um espaço reservado aos comerciantes em um período em que a elite fluminense vivia em suas chácaras nas áreas rurais da cidade, como vemos nas Memórias póstumas de Brás Cubas.

A igreja aparece como uma das principais oportunidades profissionais para os músicos no Rio de Janeiro colonial, pois não só os contratava para executar, como também para compor música sacra para suas missas. Mestre Romão, por exemplo, rege 

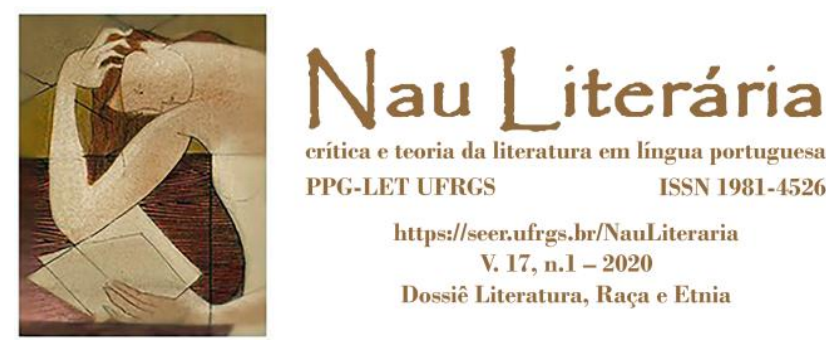

a orquestra de uma missa cantada na igreja do Carmo, enquanto o pai de Inácio Ramos era cantor na Capela Imperial, também vinculada a essa igreja. Era uma atividade ordinária, pois era comum aos músicos seguirem a carreira eclesiástica, muitas vezes sua única forma de acesso à educação, como, por exemplo, o padre/pai de Pestana ou o conhecido José Maurício Nunes Garcia, mencionado em "Cantiga de esponsais", mestre de capela e organista da Sé do Rio de Janeiro, além de diretor da Capela Real e professor. O que separa o artista do início do século dos outros dois é a presença da música sacra em oposição à popular, circunstância em que tanto o padre/pai de Pestana como o tenor pai de Inácio Ramos também se encontravam.

Nos contos que se passam durante o Império, o conflito popular/clássico se estabelece entre gêneros profanos. Inácio Ramos usa do conhecimento musical para seu sustento por meio do ensino, da apresentação em teatros, salões ou em igrejas, a rabeca sendo "um simples meio de vida" (ASSIS, 2008, p. 1566). Muitas vezes, os pais músicos ensinavam os próprios filhos, como foi seu caso e o de Pestana. Em "Um homem célebre" aparece ainda uma outra forma de usar a música profissionalmente: a venda de canções para editores, que as publicam em jornais (Figura 5) ou em partituras avulsas.

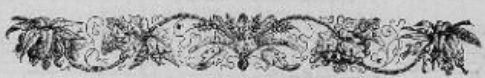

POESIA.

MODINHA.

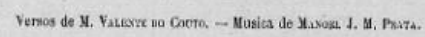

D. D. C.

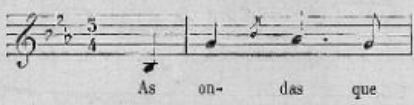



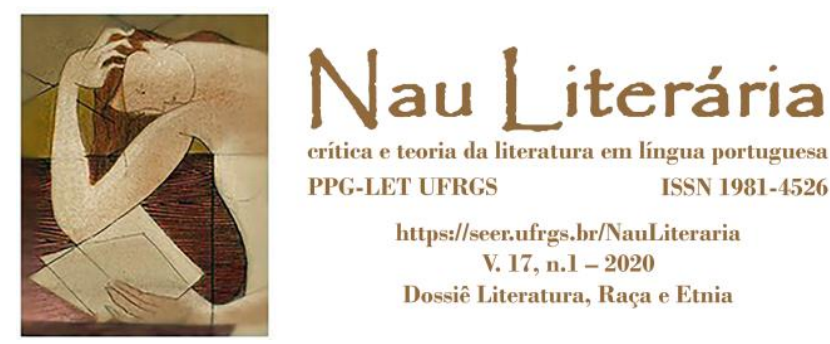

Figura 5. Modinha publicada na mesma edição do Jornal das Famílias em que foi publicado o conto "O machete". (Fonte: Hemeroteca Digital da Biblioteca Nacional).

Neste conto e em "O machete", os protagonistas também se apresentam em saraus na vizinhança, em suas casas ou em reuniões íntimas das camadas média e alta, anotadas de modo irônico pelo narrador de "Um homem célebre": "Não era baile; apenas um sarau íntimo, pouca gente, vinte pessoas ao todo, que tinham ido jantar com a viúva Camargo, Rua do Areal, naquele dia dos anos dela, cinco de novembro de 1875... Boa e patusca viúva! Amava o riso e a folga" (ASSIS, 2008, p. 464). Nesse sentido, a presença do piano nas casas fluminenses "traz consigo um fragmento prestigioso de Europa, constituindo-se nesse misto de metonímia de civilização moderna e ornamento do lar senhorial" (WISNIK, 2004, p. 42).

Já o cravo de mestre Romão era um instrumento habitual na vida musical do período colonial, tocado, por exemplo, por Nunes Garcia. Além disso, era o favorito dos ambientes domésticos, onde era mais comumente utilizado pelas senhoras (PEREIRA, 2013, p. 242). Nesse sentido, a conexão com o mundo feminino parece indicar o fato de ser o elemento mais alegre na casa do músico e a escolha da vizinha, e não de seu marido, para terminar a frase musical ao final do conto.

O violoncelo de Inácio Ramos também representa a posição de paradigma dos comportamentos e gêneros europeus. Enquanto em "O machete" a oposição se manifesta pelos instrumentos de escolha de cada artista, o piano de Pestana acaba ocupando um papel de ponte entre dois mundos cuja tentativa de conciliação ocorre pela africanização da polca. Será na insatisfação pessoal de Pestana que a contradição inerente à circunstância dos músicos se manifestará.

\section{Entre-lugar social}

Nesta leitura dos três contos de Machado de Assis procuramos focar na posição do homem livre letrado de origem africana no Rio de Janeiro oitocentista. Há em comum a estes músicos machadianos o desejo não satisfeito de compor canções de 


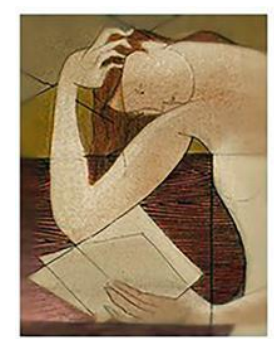

gênero elevado e de matriz europeia. A condição de afrodescendente, assim como o maxixe na história de Pestana, é acessada de modo lateral, seja pelo local de nascimento, como no caso de mestre Romão, seja pelas características físicas e pela paternidade apenas insinuada. Inácio Ramos é a personagem sobre quem menos informações são fornecidas, ainda assim, é possível inferir a origem africana em pequenos detalhes que parecem irrelevantes. Pode-se dizer que essa lateralidade resulta do fato de que

Machado trabalha esse substrato coberto de tabu - um tabu sociocultural, político, econômico, racial, sexual, existencial, cujo cerne persistente é difícil de deslindar até hoje, e que a antropologia politicamente correta, tratando-o de maneira unívoca, só faz confirmar e recobrir. Ademais, a subjetivação do mulato permanece como dimensão virgem na literatura brasileira do tempo, encontrando sua primeira expressão, posterior, em Lima Barreto. (WISNIK, 2004, p. 39).

De qualquer forma, todos eles possuem negros escravizados a seu serviço, o que aponta para uma das formas de distinção dos homens livres das camadas inferiores: a possibilidade de possuir escravizados, como bem ilustra o caso de Prudêncio, em Brás Cubas. Wisnik (2004, p. 45) chama ainda a atenção para essa presença em "Um homem célebre":

[...] o escravo, que acende o gás da sala e traz o café, é senhorialmente destratado pelo aspirante à grande arte, que o despacha, sequioso pelo usufruto da solidão: temos, na cena, uma primeira pontuação, em nota realista de passagem, da convivência entre o cultivo ambicioso da grande arte burguesa e o escravismo cotidiano.

Como destacado, os músicos retratados nos contos possuem preferência pelos gêneros clássicos europeus, considerados superiores aos populares, como as polcasmaxixe de Pestana. Mesmo os instrumentos sofrem esse tipo de divisão, como ocorre com a oposição machete/violoncelo em "O machete". Em "Cantiga de esponsais", essa diferença é tão marcada que chega a impedir o músico de congregar sua experiência de vida com o modo de composição que possui a seu alcance. Ainda assim, em seu interior, Mestre Romão sonha em compor óperas e missas. Para Nunes (2008, p. 79),

o reconhecimento social e a identidade relacionados ao ofício requeriam, numa época em que as condições de reprodutibilidade técnica da obra musical ainda não existiam, da virtuosidade na execução ou da maestria na composição. A primeira alternativa dependia da criação de oportunidades para apresentação em saraus e festas em casas de famílias mais aquinhoadas ou em salas ou teatros apropriados, bem como de tempo livre para a formação de um repertório de concerto, condições impossíveis de serem 

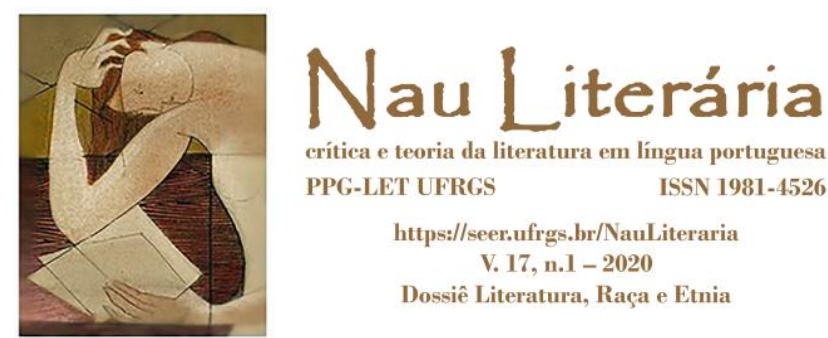

realizadas, no caso de Inácio Ramos. Restava a composição como signo distintivo da própria criação musical, cujo referente era o autor. Contudo, a hierarquia de gêneros, que existia no âmbito da produção ou da recepção, também se estendia à composição.

Desse modo, a fratura entre experiência e composição é um eixo comum na construção das personagens destes contos, cuja representação encontra-se vinculada ao contexto histórico da produção artística em cada momento retratado. Para Gledson (2006, p. 65), o entendimento do contexto musical por oposições binárias - sacro versus profano; local versus europeu; arte versus trabalho - parece simples demais. As diferenças revelam que "a mirada de Machado sobre o campo musical brasileiro do século XIX não é, portanto, binária. Como num padrão rítmico afro-atlântico, os acasalamentos são produzidos e desfeitos de forma a gerar não somente pares, mas também triângulos" (AVELAR, 2011, p. 185), de acordo com a evolução da música como cultura de massas ao longo do século. As frustrações de todos os três músicos afrodescendentes aqui estudados revelam, no entanto, uma constante: a dificuldade de constituir-se como sujeito histórico em uma sociedade escravista. Uma condição que não se resolve senão pela morte ou pela loucura.

Vinculadas a seu momento histórico específico, as contradições das personagens são as mesmas que "dão vida à prosa machadiana, que transita com certa desenvoltura entre o coloquial e o formal, o popular e o erudito, o local e o universal, o detalhe e as grandes questões" (GLEDSON, 2006, p. 66). De certo modo, são também as condições de vida e de criação de muitos dos artistas - músicos, pintores, escritores etc. - do Brasil escravista.

\section{Referências}

ASSIS, Machado de. Obra completa em quatro volumes. Rio de Janeiro: Nova Aguilar, 2008. v 2.

AVELAR, Idelber. Entre o violoncelo e o cavaquinho: música e sujeito popular em Machado de Assis. Estudos de Literatura Brasileira Contemporânea, Brasília, n. 37, p. 171-188, 2011. 

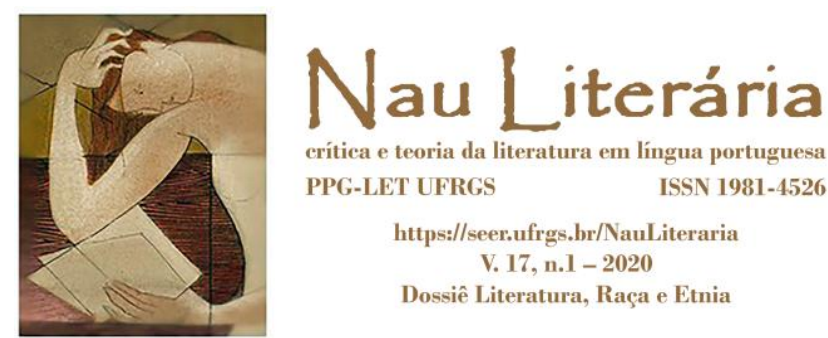

CAVALCANTI, Nireu de Oliveira. Rio de Janeiro: Centro histórico e colonial. 15672015. Rio de Janeiro: Andrea Jakobsson Estúdio, 2016.

GERSON, Brasil. História das ruas do Rio. Rio de Janeiro: Livraria Brasiliana Editora, 1965.

GLEDSON, John. O machete e o violoncelo: introdução a uma antologia de contos de Machado de Assis. In: GLEDSON, John. Por um novo Machado de Assis: ensaios. São Paulo: Companhia das Letras, 2006. p. 35-69.

GOTTO, Edward. Plan of the city of Rio de Janeiro: Brazil/surveyed in 1866 under the direction of Edward Gotto. London: Robert J. Cook, 1871. 1 atlas, 29 plantas, color., 28 cm x $42 \mathrm{~cm}$. Disponível em: <http://objdigital.bn.br/ acervo_digital/div_cartografia/ cart326448/ cart326448.pdf>. Download em: 22/04/2013.

NUNES, Jordão Horta. O machete e o violoncelo: gêneros musicais e identidade social na prosa de Machado de Assis. ArtCultura, Uberlândia, v. 10, n. 17, p. 73-88, jul.-dez. 2008.

PEREIRA, Mayra Cristina. A circulação de instrumentos musicais no Rio de Janeiro do Período Colonial ao final do Primeiro Reinado. 2013. 284 f. Tese (doutorado) - Centro de Letras e Artes, Universidade Federal do Estado do Rio de Janeiro, 2013.

PINTO, Fernanda Mousse. A invenção da Cidade Nova do Rio de Janeiro: agentes, personagens e planos. 2007. 296 f. Dissertação (mestrado) - Instituto de Pesquisa em Planejamento Urbano e Regional, Universidade Federal do Rio de Janeiro, 2007.

WISNIK, José Miguel. Machado maxixe: o caso Pestana. Teresa revista de Literatura Brasileira, São Paulo, v. 4, n. 5, p. 13-79, 2004. 